\title{
志村化工株式会社のニツケル製錬
}

\author{
正会員板 谷康 男*
}

\section{Nickel Smelting at Shimura Plant}

\section{Yasuo ITAYA}

The plant of the Shimura Chemical and Industrial Co. is the first one which is begin the production of the metallic nickel after the war in Japan. This company was at first established to produce the copper sulphate in 1946, and was changed to produce the nickel sulphate after two year's operation. The smelting of nickel was begun in 1950. The ore is imported from New Caledonia and it contains about $5 \%$ nickel. The ore is sintered by the Dwight-Lloyd sintering machine and then is charged to the blast furnace. Crude matte (Ni $30 \%, \mathrm{Fe} 55 \%, \mathrm{~S} 15 \%$ ) produced from the blast furnace is then refined in the converter and the refined matte (Ni $75 \%, \mathrm{Fe} 0.5 \%, \mathrm{Cu} 0.3 \%, \mathrm{~S}, 20 \%)$ is cast into anodes and is refined by electrolysis. The slag from the blast furnace is sold as a fertilizer. The production of the nickel of the plant was $1,356 \mathrm{t}$ in 1955, and a considerable increase of the amount of the production is expected this year.

\section{1. 緒論}

当社は今年丁度創立 10 週年右迎え，金属ニッケル製造 を開始して 7 年目である。戦後金属ニッケルの製鍊を開 始したのは当社を以て磺矢之すること在知る人は少ない であろう。また興南マット、支始め種々雑多な原料をつぎ つぎ好理して幾多の困難を重ねつつ工業的生産に成功 した事は，朝鮮動乱後のニッケル不足による異常な高洒 格に幸いされたとはいえ，当時財閥会社といえども政府 の補償援助無くしてよく遂行し得なかつた極めて見透し の困難なニッケル製鋉事業に專心し，幾多の会社が生産 中止の悲運に陷る聞に，よく技術の向上，生産原価の低 減，生産設请の合理化に努め，絶えず金融逼迫と戦いつ つ漸く昨今日本一の生座を挙げ得る態勢に至つた事は本 邦戦後事業更上特筆される心゙き事と思う。その発展の跡 は次の年間ニッケル生座量の推移が最も端的に物語るで あろう。

\begin{tabular}{|c|c|c|c|c|c|c|c|}
\hline & $\begin{array}{l}\text { 照 和 } \\
25 \text { 年 }\end{array}$ & $\begin{array}{l}\text { 照 和 } \\
26 \text { 年 } \\
\end{array}$ & $\begin{array}{l}\text { 照 和 } \\
27 \text { 年 }\end{array}$ & $\begin{array}{l}\text { 照 和 } \\
28\end{array}$ & $\begin{array}{l}\text { 照 和 } \\
29 \text { 年 }\end{array}$ & $\begin{array}{l}\text { 照 和 } \\
30 \text { 年 }\end{array}$ & $\begin{array}{l}\text { 照 和 } \\
31 \text { 年 }\end{array}$ \\
\hline 生產量 ( $\mathrm{t}$ ) & 8 & 29 & 138 & 397 & 731 & 1,356 & 1,162 \\
\hline
\end{tabular}

この間資本金も10万円から 9 億 6 阶万円に躍進しだ。

\section{2. 会社の沿革}

昭和 21 年 4 月 元野村製鋼株式会社の創立者たる堀居太 郎が硫酸銅製造の目的で資本金10万円で 会社を設立す。

*志村化工株式会社常務取縍役副工場長
昭和 21 年 9 月 東京都板橋区志村町 $2 １$ \%旧工場建設 に着手。

” 22 年 4 月 同工場において硫酸銅月痽 $50 t$ の製造開 始。

” 23 年 9 月 硫酸ニッケル製造に着手。

” 24 年 1 月 資本金 100 万円に增資し硫酸ニッケル月 産 $25 \mathrm{t}$ 製造開始。

” 25 年 1 月 電解ニッケルの試験生産開始。

" 25 年 11 月 資本金 300 万円に增資し電解ニッケル製 造装置に着手。

”26年 5 月 電解ニッケル月産 $5 \mathrm{t}$ 製造開始。

”26年 7 月 東亲都板橋区長後町 $2>13$, 旧日本マグ ネシウム工場を買収し電解ニッケル月産 25 設備の建設に着手。

” 26 年 12 月 本社を新工場に移転し一部操業を開始。

, 27年 3 月 全工場の操業在開始。

” 27 年 9 月 資本金 1,200 万円に増資。

” 27 年 10 月 資本金 3,000 万円に增資ニッケル生産設 備㺼堌強。

” 28 年 3 月 資本金 12,000 万円に増資し月産 $60 t$ 設備 趡設に着手する。

” 28 年 5 月 同設備完成。

” 28 年 12 月 資本金 24,000 万内に堌資し熔成燐肥並び にニッケル鈹の同時生産設備に着手。

” 29年11月 電解ニッケル生産能力月産 120 七なな。

”29年12月 新愹鉱炉稼動市。

”30年 5 月 肥料工場完成す。

"30年 12 月“資本金 48,000 万円に堌資し生産設備の合 
理化を期し電解ニッケル $300 t$ 生座設傹 の茟設に着手す。ニッケル地金生産能力 月産 $170 \mathrm{t}$ となる。

昭和31年 7 月 資本金 96,000 万円に増資す。

以上さらにこれを内容的に分類すると次の通りであ る。

（1），硫酸銅製造時代

（2）硫酸ニッケル製造時代

(3) ニッケル製鍊時代
a. 與南マッ卜好理期
以上旧坂上工場
b. ニッケルスパィス㚭理期 以下現工場
c.クリーニングメタル观理期
d. ニッケルキャタリスト処理期
e. ニッケル鉣石委託製錄期
f. 鉱石より一貫生産期
以下やや詳細に述へる。

\section{3. 硫酸銅製造時代}

(自昭和21年 4 月 至昭和 23 年12月)

戦災による焼故銅を原料として，硝酸古酸化剤として 用いる硝硫酸の混酸溶解法による硫酸銅门製造を行う た。製造装置はほとんぞすべてステンレス在使用して硝 酸回收塔虎設け, 溶解に伴つて発生する正硝酸ガス虎空 気酸化し，これを水に吸収させて硝酸約 $95 \%$ 䘮回収利用 し，純度 $99.5 \%$ の優秀なる硫酸銅月産 $50 \mathrm{t}$ 怒製造した。 主として製品は全国の農業会(後の全購連)に納入した。 なおインド向 $100 \mathrm{t}$ の輸出を行つたが後に流生産過剩之 なり硫酸ニッケルが鍍金心需要增て逼迫の状樊となつた ので，硫酸ニッケル製造に転換した。

\section{4. 硫酸ニッケル製造洔代 \\ (自沼和 23 年 9 月 至昭和 26 年 5 月)}

主原料は戦時中のニッケル地金及び啗虎利用し，製造 装置及び溶解法は，硫酸銅之全く同一であつたが，不純 物除去のための浄液法觉苦心研究優秀な製品点, 月印の 名称の下に出した。生産も月産 $30 \mathrm{t}$ に達し当時として は，日本一の生産実績虎挙げた。なおニューヨーク向10 七の輸出は，米国向唯一のケースであつた。しふしなが らこれまた次第に甫場飽和状態となりついに激烈なる 価格競争となるに至り，経営著しく困難な極めついに社。 長の英断古もつて電解ニッケル製造度決意従業員また給 料遅配の哏苦在忍びつつも決然之新涀事業に突入した。 当社の運命は㿤にこの時期にあつた。

\section{5. ニッケル製錬時代}

$5 \cdot 1$ 電解ニッケル試作 (興南マッ) (鼻昭和25年1 月 かくして昭和 25 年 1 月より戦後日本で初めての金属

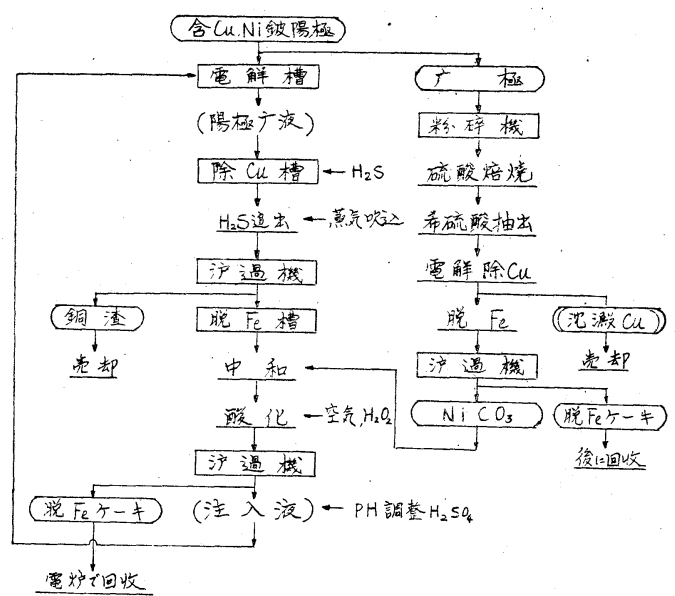

第1図 興南マット迈理工程署

ニッケルの試験生座が開始された。しかしながら当時二 ッケル製錬に関子る文献もほとんど皆無に等しく，かつ またニッケル製錬技術つ経験者もいなかつたのて試作研 究は困難を極めた。原料は戦時中日本空素興南工場で朝 鮮産ニッヶ儿鉱石虑原料として，製造されたいわゆる興 南マットでこれを産業復興公団より 2 百数 10 購入した ものでその成分は打抢よそ Ni 48\%, Co 1\%, Cu 18\%， Fe.6\%, S 20\% As 0.5\%, Zn 1.5\%てあつた。れれ友

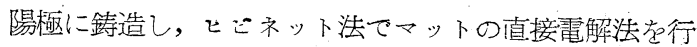
つた。廃液の $\mathrm{Cu}, \mathrm{As}, \mathrm{Zn}$ 等つ不純物を $\mathrm{H}_{\mathrm{S}} \mathrm{S}$ て除去し た後 $\mathrm{Fe}$ 走 $\mathrm{NiCO}_{3}$ で中和, $\mathrm{H}_{\mathrm{g}} \mathrm{O}_{9}$ て酸化除去し $\mathrm{H}_{5} \mathrm{SO}_{4}$ で $\mathrm{pH}$ 調製を行つた。電解液は硫酸ニッケル液で Ni 40 $\mathrm{g} / 1$, 邵酸 $20 \mathrm{~g} / 1$, 液温 $50 \sim 60^{\circ} \mathrm{C}$, 電流密度 $200 \mathrm{~A} / \mathrm{m}^{2}$, 槽 電压 $5 \mathrm{~V}$ であつた。陸極板は 5 枚吊, 電槽は 24 槽 $(900$ $\mathrm{mm} \times 900 \mathrm{~mm} \times 900 \mathrm{~mm})$, 電動発電機は $260 \mathrm{PP} 115 \mathrm{~V} \times$ 1,200A 1 台で製品の大きさま $150 \mathrm{~mm} \times 600 \mathrm{~mm}$, 品优 ほ $\mathrm{Cu} 0.05 〜 0.5 \%, \mathrm{Fe} 0.05 \%$ 0.5\% でバシッキが多 ふつたが，ともかくマットの直接電解に成功した。その 工程老第1図に示す。

$\mathrm{Cu}, \mathrm{Fe}$ ⿸在極めて多量に含さマットの直接電解法であ つたためにしぱしば剥離や電着障害に遭遇し辛酸克嘗め たが社長のたゆまざる熱意と努力とは，ついにあらゆる 困難を克服して成功し生産も月蓙 $5 \mathrm{t}$ に達し, 当時とし ては日本一の生産高であつた。たまたま朝鮮事变勃発文 るに伎んでニッケルの需要が急增し価格も月を逐うて騰 貴し $\mathrm{t}$ 当り 200 万円を超えるに及びついにニッケル需 給調整規則が施行されるに至つた。ここにおいて政府も ニッケルの増座を奖励する気運となり，当社もまた日本 マグネシウム東京工場芷買収してニッケルの增座に積極 的に乘出子に至つた。

$5 \cdot 2$ ニ

上記興南マットも終り存告け戦時中台湾花蓮港に東邦 


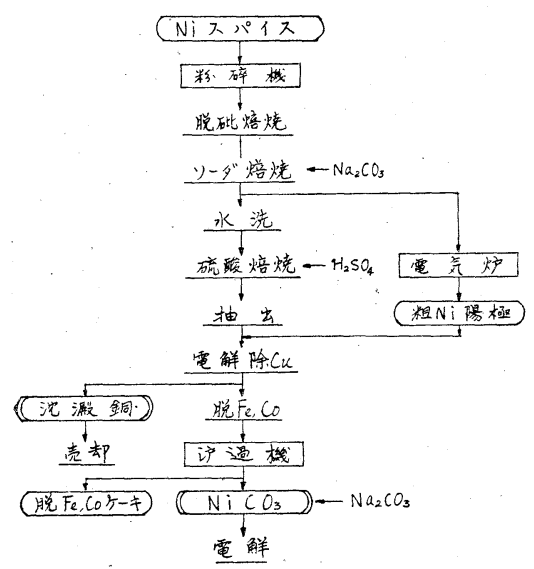

第 2 図ニッケルスパイ ス製鍊系統図

金属製錬が所有していたもの虐戦後逆輸入してこれの製 鍊を企図したが製鍊の可否を巡つて大分問題とされた事 もあつたが，飽く迄これが可能なっ老確信し，苦心研究 の末後に述べ方法て高品位ニッヶルの生産に成功し た。昭和 26 年 7 月漸く日本マグネシウム東京工場门主要 部約 12,000 坪克買収し直ちに月座 $25 \mathrm{t}$ の電解設備及る゙ 製錬設備の建設に着手同年 12 月より操業に入つた。

これの原料はごルマ, 永ードウイン鉱山の鉛製鍊门副 應物てあつてその成分は拉拉よそ Ni $30 \%$, Co $4 \%, \mathrm{Cu}$ $11 \%, \mathrm{Fe} 1.5 \%$, As 35\%, Sb 3\%, Pb 6\%である。そ の製鏳の概要は第 2 困のようにまず多量のAs 友除去す

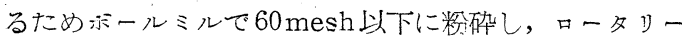

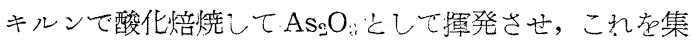
䂤室に導き冷却沈洪させた。次に焙焼物を反射炉でン一

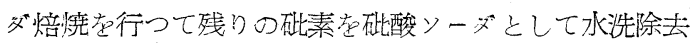
乙酸化ニッケルとした。これ老硫酸之混和焙焼して抽出 しこの抽出液门銅分を $200 \mathrm{kVA}$ 電気炬で還元愹融した 粗ニッケル陽極で電解除銅して Cu 分を除去した後，炎 酸ニッケルとなし，これを不溶泩陽極電解法にて電解製 䤼を行つた。電解液は硫酸ニッアル液て $\mathrm{Ni} 40$ 〜 $50 \mathrm{~g} / 1$, 咴酸 $20 \mathrm{~g} / 1, \mathrm{pH} 2 \sim 3$, 液温 $50 \sim 60 \mathrm{C}^{\circ}$, 電流密度は 130 $\mathrm{A} / \mathrm{m}^{2}$, 槽電王 $4 \mathrm{~V}$, 極間距離:は $80 \mathrm{~mm}$, 陽極は当初力ー 亦ンを使用したが後に鉛に変えた。
兰時つ成品つ一例は $\mathrm{Ni} 98.40, \mathrm{Co}$ 1.06, $\mathrm{Cu} 0.04, \mathrm{Fe} 0.08$ であつた。 本社工場 敷地 10,500 坪 建物 3,593 坪

坂上工場 敷地 1,400 埰 建物 : 600坪

5.3 スラッグ・クリーニング - メタル処理期

(自昭和 27 年 4 月 至䧂和 27 年 9 月)

次いで新たに相互貿易 (株) を通 してノールけェイのファルコンプリ ッデ社のステッグ・クリーニング・メ タル約 400 tの買付在行いこれを処 理した。この原料の組成はほほ $\mathrm{Ni}$ グメタル処理工程図 35 45\%, Cu 7.5\%, Co 3\%, Fe 40\%, As 1.5\%, Si $10 \%$ Ci の含有極めて高いのが特徵であり，当時熔 鉱炬，転炬の設㣁の無いためこれが処理には困難范極め た。王子化成はこのためついに倒産の止さなきに至つ た。な抢当時日本電気治金も約 $50 t$ 買付けたがこれも ほとんど末処理つまま放置された。

当社にててこの硫化，脱鉄には第 3 図工程により行つ たが满足すへきものでなく，最後に日本鉱業日立整鏏所 に精鍊委託を打願いして漸く目的之する精鈹が得られた が販売価格の低下とともにほとんぎ利益学挙げることが 出来京かつた。

この工程つ概要はキューポラでニークスとともに熔 解し，前炉に抢いて愹湯に固体硫黄在直接投入硫化をは かつたが Si の残留するため偏析在生じ完全硫化が困難 であつた。さらにこれを真吹炬，反射吙，小型電気炉で酸 化剂存もつて脱鉄したが,鉄分 5〜10\%程度が残留した。 なお日本鉣業では硫化鉣とともに愹鉣炬で愹融 Ni 20\% 程度の粗鈹趸転师に投大冷材（クリーニングメタル）存 逐次投入し珠石を flux として空気にて脱鉄したが始め はクリーニングメタル中の Si の燃焼にょつて温度が著

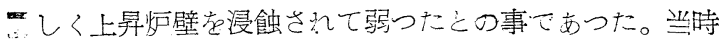
压の成分の一例 Ni $99.52 \%$, Co $0.34 \%, \mathrm{Cu} 0.02 \%, \mathrm{Fe}$ 0.03\%であつた。

第 1 表 主要没䄍の概裂 (昭和 27 年 2 月)

\begin{tabular}{|c|c|c|c|c|}
\hline $\begin{array}{l}\text { 製 鍊 } \\
\text { 工程別 }\end{array}$ & 設 菕 名 称 & 台数 & 式 & 能 \\
\hline 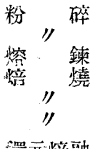 & 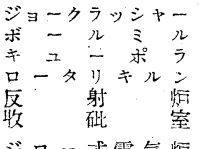 & $\begin{array}{l}1 \\
1 \\
1 \\
1 \\
1 \\
4\end{array}$ & $\begin{array}{l}10^{\prime \prime} \times 20^{\prime \prime} 40 \mathrm{P} \\
\phi 1.5 \mathrm{~m} 50 \mathrm{P} \\
\$ 650 \mathrm{~mm} \mathrm{~h} 4.5 \mathrm{~m} 7.5 \mathrm{P} \\
\phi 1.22 \mathrm{~m} \times \mathrm{L} 12.5 \mathrm{~m} \\
\mathrm{w} 1.8 \mathrm{~m} \times \mathrm{L} 13 \mathrm{~m} \\
5 \mathrm{~m} \times 3 \mathrm{~m} \times 50 \mathrm{~m}\end{array}$ & $\begin{array}{l}2 \mathrm{t} / \mathrm{hr} \\
1 \mathrm{t} / \mathrm{hr} \\
1 \mathrm{t} / \mathrm{hr} \\
0.5 \mathrm{t} / \mathrm{hr} \\
4 \mathrm{t} / \mathrm{H} \\
\end{array}$ \\
\hline 䇺儿暗䖪 & ジロー式電気贸 & 2 & $200 \mathrm{kVA}$ & $100 \mathrm{~kg} /$ 每回 \\
\hline $\begin{array}{l}\text { 電 鎮 } \\
\text { "/ } \\
\text { "I } \\
\text { I/ }\end{array}$ & 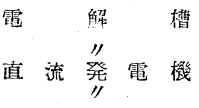 & $\begin{array}{r}48 \\
24 \\
1 \\
1\end{array}$ & $\begin{array}{l}900 \mathrm{~mm} \times 900 \mathrm{~mm} \times 1,400 \mathrm{~mm} \\
900 \mathrm{~mm} \times 900 \mathrm{~mm} \times 1,000 \mathrm{~mm} \\
350 \mathrm{P} 105 \mathrm{~V} 2,400 \mathrm{~A} \\
260 \mathrm{P} 125 \mathrm{~V} 1,200 \mathrm{~A}\end{array}$ & 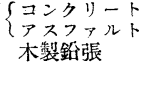 \\
\hline
\end{tabular}

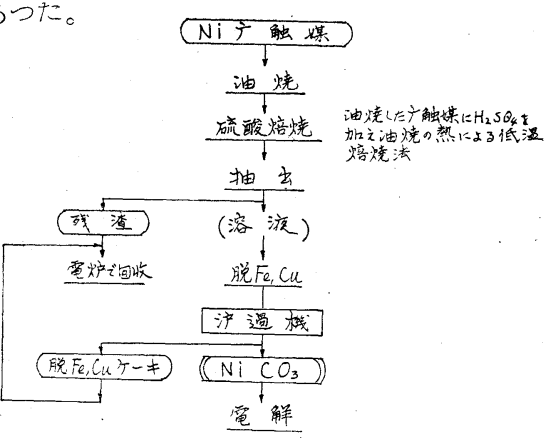

䇥 4 図 ニッケル廃触媒㚭理工程図 


\section{$5 \cdot 4$ ニッケル廃触媒処理期（眰昭和27年10月）}

昭光商事を通してカナメ゙の亦ロック社よりカナメ゙およ びアメリカの硬化油の廃触媒龙輸入した。この成分は Ni $5 \sim 10 \%$, 動植物油20〜 50\%残部は珪藻土であつた。

まず油を除去するため 2,3 の油脂会社に委託, 檢化法, 抽出法等により含有油脂を有効に分離回収することを試 みたが当時はすでに油脂過剩時代に大り，また能力的に 短期間大量の処理が困難てあったため,ついに断念し第 4 図工程のように直接燃焼法により油を除士した後, 硫 酸抽出乙岸酸ニッケルとなし, 前回同様不溶性陽極法て 電解ニッケルを製造した。

当時の製品の一例は $\mathrm{Ni} 99.61 \%, \mathrm{Co} 0.29 \%, \mathrm{Cu} 0.016$ $\%, \mathrm{Fe} 0.049 \%, \mathrm{~Pb}$ 0.012\% であつた。

\section{5 珪苦ニッケル鉱熔錬委託期（眰照和28年 1 月 2 月}

上記種々雑多な原料を処理したが量的継続的に入手が 困難になつたためと品質问上生産原価の切下の見地から 鉣石よりの一貫生産が必要之なつたため尼崎市関西電気 製鉄（旧日銑工業つ第二会社）が開放型電気炬及び鉄鋼 精鍊用転炉を有すのに著目し，己れを萃下に絊合して昭 和28年 1 月21日より野崎産業扱ニューカレドニヤ産ニッ ケル鉣石 (Ni 5.15\%) て開放型ェルー式電気炉 3,000 $\mathrm{kVA}$ にて鉣石製錪を開始し粗鈹を製造し，これを改造 した転启にてアノードとした。なお同年 2 月 6 日には帝 国製鉄升森工場においてて木孷銑榕鉣炬により同じ鈗石で 粗鈹つ生座を開始し，これを関西電気製鉄に送つて精鈹 となし，陽極板に鋳造して，志村化工においてとごッ ト法でニッケル電解を行った。のらに同社三成工場の木 炭銑愹鉙炬て粗鈹の生産を継続し昭和 29 年 6 月まて生産 を行つた。生産能力は鉱石処理量月 1,200 t程度であつ た。次いで昭和29年に入って関東電工倉賀野工場, 日出 化学舞鶴工場て熔成隣肥の同時生産を東北電化岩村田工 場，新報国製鉄富山工場に抢いて単独生産を第 5 図のよ うに行つたが，日出化学以外は技術未熟，煙害問題等の ため所期の生産举らず，原価また高きにつき何れも年内 に休止するに至つた。この時期に志村化工においては新 たに電解槽32槽次增設しマットの直接電解法により高純 度の電解ニッケル生掂に成功した。その概要は次の通り である。

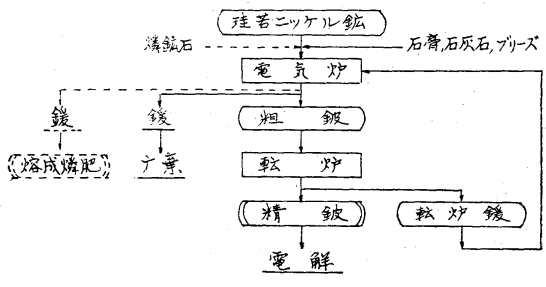

第 5 図 珪苦 =ッケル鈗委託製鍊系統図
電 解 液

$$
\begin{array}{lll}
\text { 硫酸ニッケル } & \mathrm{Ni} & 40 \sim 50 \mathrm{~g} / 1 \\
\text { 硼 } & \text { 酸 } & 20 \mathrm{~g} / 1 \\
\text { 液 } & \text { 温 } & 50 \sim 60^{\circ} \mathrm{C}
\end{array}
$$

電流密度 $135 \mathrm{~A} / \mathrm{m}^{2}$

槽 電 压 $3.7 \mathrm{~V}$

極間距離 $85 \mathrm{~mm}$

電槽の大きさ 巾 $900 \mathrm{~mm} \times$ 長 $2,200 \mathrm{~mm} \times$ 深 $1,500 \mathrm{~mm}$

陰極の大きさ $750 \mathrm{~mm} \times 850 \mathrm{~mm} \quad 12$ 枚吊

陽極の大きさ $230 \mathrm{~mm} \times 900 \mathrm{~mm} \times 30 \mathrm{~mm} \quad 39$ 枚吊

製品の品位 $\mathrm{Ni} 99.56, \mathrm{Co} 0.36, \mathrm{Cu} 0.021$,

$\mathrm{Fe} 0.018, \mathrm{~Pb} 0.005 \%$ ，S 0.001

\section{6 志村化工東京工場における鉱石よりの一貫生産 (昭和 29 年 12 月以降)}

かねてニッケル地金のコスト切下を研究中の処熔成膦 肥との同時生産方式による他無きを痛感，志村化工東京 工場に抢いて鈗石よりの一貫生産設徣並びに熔成燐肥製 造設備を建設すべく昭和29年早々着手中の処，たまたま ニッケル夺況の悪化に遭遇一時停滞の止さ無きに至り， 上記の上うな日出化学他数工場に鉱石の委託精錬を行つ たが，生産は所期のように挙らず，このままではジり貧 の状態となる抢をれがあるため，炤和29年10月に急拠完

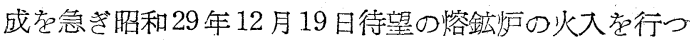
た。生産も逐月上昇し翌昭和 30 年 3 月には転炉も完成， ここに始めて鉱石よりの一貫生産態勢が整つた。同年 6 月には肥料工場も完成稼働に入りニッケル鈗㳯から苦士 珪カル肥料の生産を開始した。

\section{熔鍊設備の概要}

イ. 焼 結 機

型式 ドワィトロイド型バルト式，米国アサ ーマッキー社設計, 三菱造船広島造船 所製作

能力 $200 t /$ 日

パレット巾 $1,385 \mathrm{~mm} \times$ 長 $500 \mathrm{~mm}$ 47個 有効面積 $10.4 \mathrm{~m}^{2}$, 有效長さ $7.6 \mathrm{~m}$

パンット速さ $500 \mathrm{~mm} / \mathrm{min}$

排 風 機 圧 力 $-1,000 \mathrm{~mm}$ 水柱

風 量 $600 \mathrm{~m}^{3} / \mathrm{min}$

電 動 機 $300 \mathrm{PP}$ 1,500rpm

口. 愹鉱炉型式 半水套式上抜排煙

能力乾鉣 $200 \mathrm{t} /$ 日

主 要 寸法 羽口準の大きさ 巾 $1.2 \mathrm{~m} \times$ 長 $6.1 \mathrm{~m}$ 羽口準よりの高さ $4 \mathrm{~m}$ 羽口径 $130 \mathrm{~mm}$, 片側18個, 計36個 岁内容積 $40 \mathrm{~m}^{3}$

前 炉 内径 $1.8 \mathrm{~m} \times$ 深 $1.4 \mathrm{~m}$

トンンス $200 \mathrm{kVA} \times 2$ 基 
送風機 圧 才 $1,000 \mathrm{~mm}$ 水桂

風量 $500 \mathrm{~m}^{3} / \mathrm{min}$ 電動機 $200 \mathrm{HP} 3,000 \mathrm{rpm}$

八. 転师

型式 バーレル型 2 台, 古河鉣業足尾製作所

能力 粗鈹処理量 $10 \mathrm{t}$ / / 回

主要 寸法 $\phi 1.9 \mathrm{~m} \times \mathrm{L} 2.7 \mathrm{~m}$

羽只 $\phi 32 \mathrm{~mm} \times 10$ 本

送風穖風量 $112 \mathrm{~m}^{3} / \mathrm{min}$

風圧 $0.84 \mathrm{~kg} / \mathrm{cm}^{2}$

電 動機 $300 \mathrm{PP} 3,000 \mathrm{rpm}$

二. 電 解 槽

巾 長 深 槽数

第一電槽 木 製 鉛 張 $920 \quad 2,420 \quad 1,50020$

第二電槽 $\quad 9202,220 \quad 1,50032$

第三電槽 ユンクリー成澍脂張 $920 \quad 2,694 \quad 1,500 \quad 12$

第四電槽 禾製 鉛 張 $920 \quad 2,220 \quad 1,50016$

第五電槽 " $9202,2201,50024$

計 104 榑 能力 $170 t$ /日

カソード12枚吊 アノード39枚吊

·電動発電機

$\begin{array}{rrrrr} & \text { 台数 } & \text { 電压 } & & \text { 電流 } \\ 500 \mathrm{H} & 2 & 180 \mathrm{~V} & \times & 2,100 \mathrm{~A} \\ 350 \mathrm{P} & 1 & 90 \mathrm{~V} & \times & 2,400 \mathrm{~A} \\ 260 \mathrm{H} & 1 & 1,200 \mathrm{~V} & \times & 1,200 \mathrm{~A}\end{array}$

东. 肥料工場

能 力 $6,000 \mathrm{t} /$ 日

乾燥設備 ローダリーキルン $\phi 1.5 \mathrm{~m} \times 20 \mathrm{~m} 10 \mathrm{t} / \mathrm{hr}$

粉 硶 ホホールミル $4 \mathrm{ft} \times 8 \mathrm{ft}$

$200 \mathrm{PP}$ 1台 $10 \mathrm{t} / \mathrm{hr}, 250 \mathrm{PP}$ 1台 $10 \mathrm{t} / \mathrm{hr}$

袋 詰 パッカー大和式自動袋詰計量器三連式

\section{熔錬作業の裉要}

$$
2 \text { 台, 各 } 10 \mathrm{t} / \mathrm{hr}
$$

東京港より艅 $(100 〜 150 \mathrm{t})$ にて隅田川点上り志村工 場岸壁に荷揚けしたニッケル鉣石は第 6 四のように塊之 粉にフルイ分し，粉鉱はDL 型焼結機でブリーズ約 $13 \%$ にて焼結し塊鉣とともに鉣石当り石膏 $13 \%$,石灰石 $40 \%$ ，

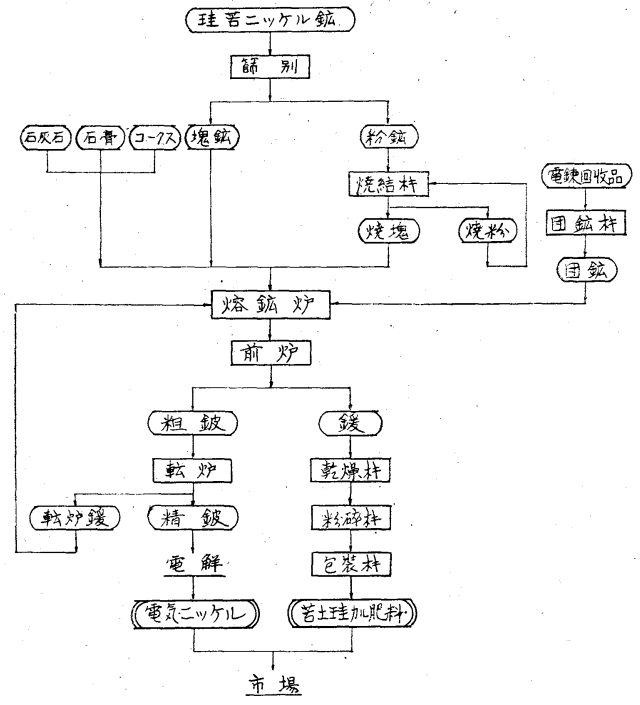

第 6 図 ニッケ几製鍊一貫操業系統図

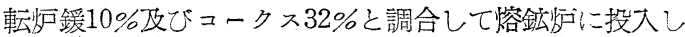
風圧水銀柱 50 ～60mm て愹鍊する。粗鈹 ( $\mathrm{Ni} 30 \%, \mathrm{Fe}$ $55 \%$ ，S 15\%）を前师より約 3 時間ごとにタップし転炉 に投大する。転师で精製された精鈹（Ni 75\%， Fe 0.5\%， $\mathrm{Cu} 0.3 \%$, S 20\%) は鋳型に鋳込从陽極として電鍊工場 に送付される。

この際生ずる転炉鍰 (Ni 1.5\%, $\mathrm{SiO}_{2} 20$ 20\%, Fe 45〜55\%) は愹鉣炬に戻す。一方愹鉣炉鍰 $\left(\mathrm{SiO}_{2} 40 \sim 45\right.$ $\%, \mathrm{CaO} 20 \sim 22 \%, \mathrm{MgO} 15 \sim 20 \%, \mathrm{FeO} 10 \sim 18 \%$, $\mathrm{Al}_{2} \mathrm{O}_{3}$ 4 5\%, Ni 0.15 0.20\%) は絶元す前炬より流出 乙，水碚して水切され，ロータリーキルンにて乾燥，示 ールミルにて粉碎，包装機にて袋詰の上苦土珪カル肥料 として市場人出される。

\section{電解作用の概要}

電解液組成及び電解條件等は前期之同様，陽極豦液は $\mathrm{Cu} 30 \sim 50 \mathrm{mg} / 1, \mathrm{Fe} 30 \sim 50 \mathrm{mg} / 1$, その他極少量 $\mathrm{As}, \mathrm{Pb}$, $\mathrm{Sb}$ 等がある。これて鉄粉にて銅置換除去し，脱鉄槽に 佶いて炭酸ニッケルで中和，空気を吹込み塩素を注入乙

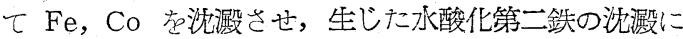

第 2 表 新嫢增設計画による主要設碏の概要 (昭和 31 年 8 月)

\begin{tabular}{|c|c|c|c|c|c|}
\hline 俑 & 称 & 台数 & 式 & 容 & 能 \\
\hline 燒結設 備 & 焼結機 & $\begin{array}{l}1 \\
1 \\
\end{array}$ & $\begin{array}{l}\text { 代ワイトロイド型 } \\
\text { 片吸込ターボフン }\end{array}$ & 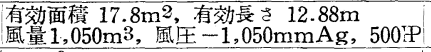 & $300 t /$ 日 \\
\hline 熔鍊設 備 & 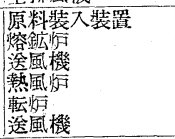 & $\begin{array}{l}1 \\
1 \\
2 \\
3 \\
2 \\
1\end{array}$ & 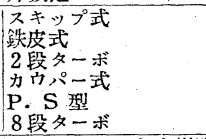 & 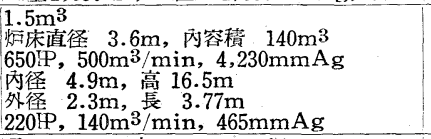 & $\begin{array}{r}1,000 \mathrm{t} / \mathrm{\theta} \\
300 \mathrm{t} / \mathrm{\theta} \\
15 \mathrm{t} / \text { 回 }\end{array}$ \\
\hline 電槽設 備 & 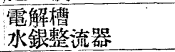 & 180 䏆 & 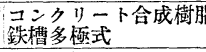 & $\begin{array}{l}\text { 長 } 2.51 \mathrm{~m} \text {, 巾 } 445 \mathrm{~mm} \text {, 深 } 1.66 \mathrm{~m} \\
900 \mathrm{~V}, 600 \mathrm{~A}\end{array}$ & $270 t /$ 月 \\
\hline 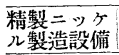 & $\begin{array}{l}\text { 電気沙閏放型 } \\
\text { 型 } \\
\end{array}$ & $\frac{1}{2}$ & 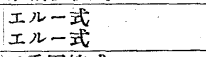 & $\begin{array}{l}2,000 \mathrm{kVA} \\
2,000 \mathrm{kVA}\end{array}$ & $\begin{array}{l}100 \mathrm{t} / \text { /月 } \\
100 \mathrm{t} / \mathrm{H}\end{array}$ \\
\hline 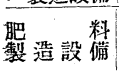 & $\begin{array}{l}\text { 口ータリドライヤ } \\
\text { チューブミル } \\
\text { 袋誌機 }\end{array}$ & 2 & 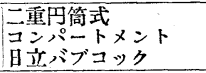 & $\begin{array}{l}\text { 直㗱 } 2 \mathrm{~m} \text {, 長 } 15 \mathrm{~m} \\
\text {, }\end{array}$ & $\begin{array}{l}10 \mathrm{t} / \mathrm{hr} \\
10 \mathrm{t} / \mathrm{hr}\end{array}$ \\
\hline
\end{tabular}

$\mathrm{As}, \mathrm{Sb}, \mathrm{Pb}$ 趸酸化共着 せしめ除去する。

最近における電解ニッ ケルの品位は次の通りて ある。

$\mathrm{Ni}+\mathrm{Co} \quad \mathrm{Co} \quad \mathrm{Fe}$ $99.95 \% \quad 0.3 \% \quad 0.005 \%$

$\mathrm{Cu} \mathrm{Si}, \mathrm{Mn}, \mathrm{As} \mathrm{C}$

$0.005 \%$ tr $0.005 \%$

$\mathrm{Pb} \quad \mathrm{S}$

$<0.001 \% \quad 0.001 \%$ 


\section{6. 增設計画の概要}

近時内外に抢けるニッケル需給の逼迫に再会し，次の ような概要の増設計画を昨秋樹て逐次完了, 電解工場の 半分及びェルー式開放電気炉は完成しすてに稼動に入 り，10月には新設熔鉙炉も稼動し生産飛躍的に增大，月 産 400 t以上に達する見込である。

\section{7. 結一言}

以上ニッケル電解の試作以来僅か 7 年にしてその品質
世界的水準に達し，米，英，独始め遠く海外諸国に輸 出するに至つたことは顧りみて詢に感概にたえない。

当社のニッケル製錬当時の苦難畤代に寄せられた大方 の並々ならぬ援助之激励とに対し厚く感謝しなおまた 技術的には戦前日本でニッケル製錬を開始せられた先人。 の妢力に負うところ極めて大てあらた事在あらためて感 謝する次第てある。

\section{堆積磁性廃石中の灰重石の回收}

米国 Nevada-Massachusetts Co.のネバダ州 Tungsten にある $600 \mathrm{t}$ 選鉱工場では, テーブルで採 収した灰重石精鉣をフラッシュ・ロ ーステイングに付した後, 磁選によ つて精選夲行つている。ところがこ の磁選で除去される磁性廃石中に, 多少の灰重石が冕失しているので， これを回收する目的て $2 \mathrm{t} / \mathrm{h}, 1$ 方操 業の小選鉣工場を撸設した。この磁
性廃石は粒度約 48 mesh, 品位は $1.5 \sim 12 \% \mathrm{WO}_{3}$ である。

この小工場の選鉣系統は下図に示 す通り，2段破䂶，ロッドミル粉 砕，硫化物浮選，サイクロン分級， テーブル, 焙焼, 磁選から成る。浮 選尾銗を分級する湿式サイクロンの 要目は，中筒部内径 $75 \mathrm{~mm}$, 流大圧 $1.2 \mathrm{~kg} / \mathrm{cm}^{2}$, 流入口寸法 $19 \times 9.5 \mathrm{~mm}$, オーバフロー・ファインダ内径 19 $\mathrm{mm}$, アンダフロー・ノズル内径 $13 \mathrm{~mm}$ である。

硫化物浮選に使用される試薬は, ザンセート $\mathrm{R} \# 242$ (エロフロート)。な拈ジョ 一・クラッシャと浮選機にンーダ灭 を添加し，また腐蝕防止のためにシ ックナに珪酸ソーダを添加してい る。

How to Boost Scheelite Recovery. EMJ, Nov. 1956, p. 105 \&: v。

(今泉)

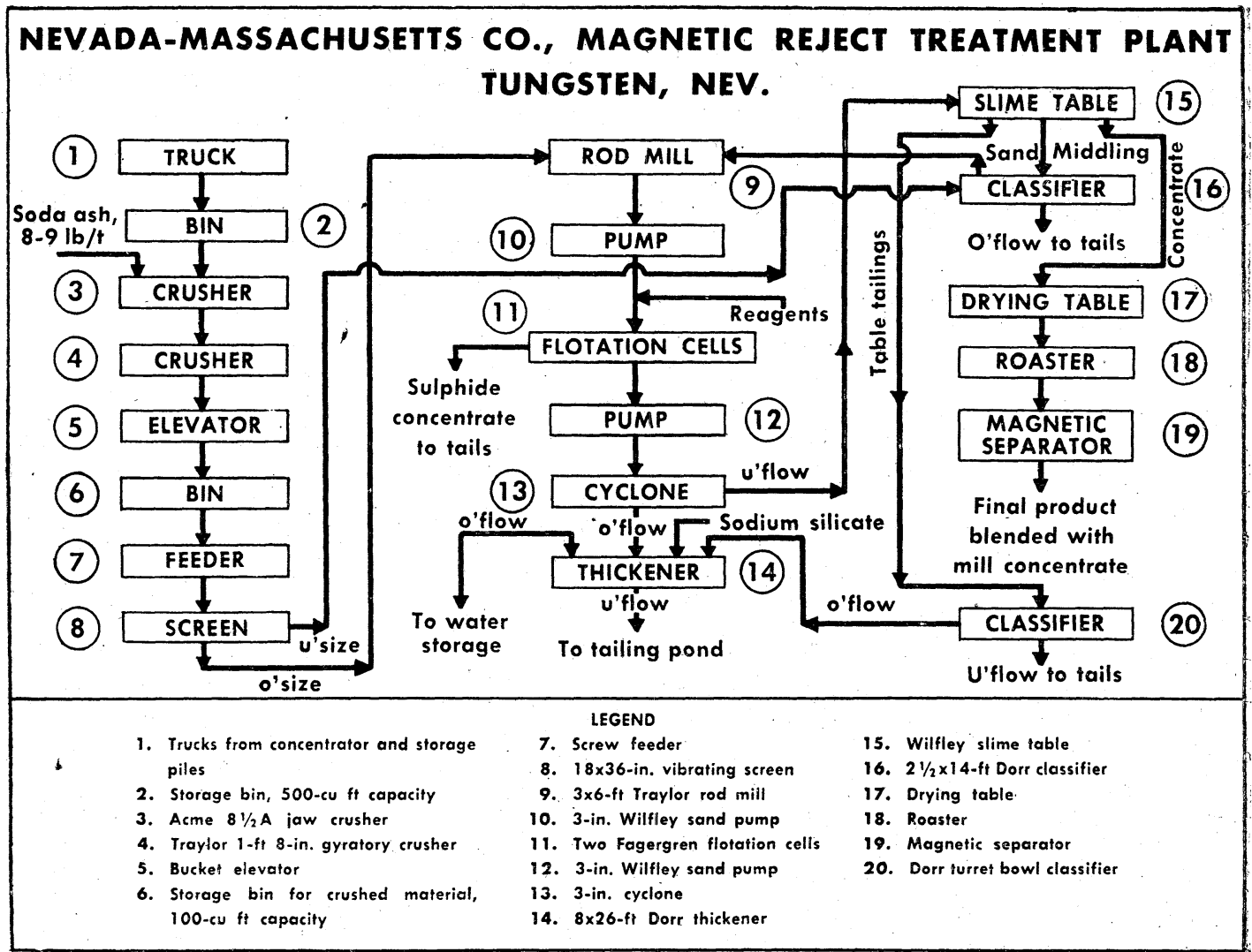

